\title{
Biomass burning response to high-amplitude climate and vegetation changes in Southwestern France from the Last Glacial to the early Holocene
}

\author{
Damien Rius • Didier Galop · Elise Doyen • \\ Laurent Millet $\cdot$ Boris Vannière
}

Received: 15 October 2012/ Accepted: 10 November 2013/Published online: 6 December 2013

(c) Springer-Verlag Berlin Heidelberg 2013

\begin{abstract}
The main drivers of fire regimes in southern Europe are climate, vegetation and land-use changes that interact at different spatio-temporal scales. These complex interplays between "natural" and anthropogenic forcings hinder the identification of fire-climate linkages on the long time scale. In this paper, we focused on the Last GlacialHolocene transition, which is the last time Europe experienced rapid warming of similar magnitude and rate of change as predicted for the future, and with minimal human impact (no agricultural activities). We derived fire activity from two neighbouring lacustrine macrocharcoal records, Ech paleolake and Lake Lourdes, located $3 \mathrm{~km}$ apart. To understand the effect of external forcings, we reconstructed summer $\mathrm{T}^{\circ}$ changes and vegetation dynamics from two independent proxies. We then compared both paleofire records with chironomid-inferred summer air temperature reconstruction from Ech paleolake. We discuss the role of vegetation type, structure and biomass availability using pollen analysis from Ech paleolake and Lourdes. Fire activity is strongly modulated by summer $\mathrm{T}^{\circ}$ oscillations as shown by the highly contrasted responses between the Oldest Dryas/Interstadial and Younger Dryas/ Holocene transitions. However, vegetation type and biomass availability act as limiting factors: the slight increase
\end{abstract}

Communicated by J.-L. de Beaulieu.

D. Rius $(\varangle) \cdot$ E. Doyen $\cdot$ L. Millet $\cdot$ B. Vannière

Laboratoire Chrono-Environnement, UMR 6249 CNRS,

Université de Franche-Comté, UFR ST, 16 Route de Gray,

25030 Besançon, France

e-mail: damien.rius@univ-fcomte.fr

D. Rius · D. Galop

Laboratoire GEODE, UMR 5602 CNRS, Université Toulouse

II-le Mirail, 5 Allées Antonio Machado, 31058 Toulouse, France in fire activity at the onset of the Interstadial is triggered by a $7{ }^{\circ} \mathrm{C}$ summer $\mathrm{T}^{\circ}$ increase but remains limited by low availability of woody biomass in a steppe environment. On the contrary, the onset of the Holocene is characterised by a $2{ }^{\circ} \mathrm{C}$ summer $\mathrm{T}^{\circ}$ increase and an unprecedented increase in fire activity, conditioned by the establishment of dense deciduous forests.

Keywords Fire $\cdot$ Charcoal $\cdot$ Late-Glacial . High-amplitude climate change $\cdot$ Pyrenees

\section{Introduction}

Among the potential effects of global climate change, the increase in wildfire intensity and frequency has been pointed out as a major environmental threat (IPCC, Schneider et al. 2007). In southern Europe and western USA, area burned, fire severity and event frequency are already being impacted by global warming through increased drought (Pausas and Fernandez-Munoz 2012) and earlier onset of spring (Westerling et al. 2006). In Mediterranean Europe, increased summer temperatures are expected to lengthen fire season (Giannakopoulos et al. 2009). However, climate and fire are not linearly linked as other interacting drivers (e.g. vegetation and/or land use changes) may interfere at annual (Zumbrunnen et al. 2011) to centennial and millennial scales (Higuera et al. 2009; Rius et al. 2011). This combination of multiple factors also accounts for a non-spatially uniform response of fire regimes to global warming (Flannigan et al. 2009).

Despite modelling efforts that increasingly use palaeofire data (Bergeron et al. 2010; Pechony and Shindell 2010) to evaluate the outputs of future fire scenarios, the response of fire regimes to rapid and high amplitude climate 
changes, both past and present, has received little attention (Krawchuk et al. 2009; Marlon et al. 2009), in particular in temperate Europe. Palaeoecological fire studies can supplement monitored data (meteorological and fire databases) that are rarely available for before the 20th century, to identify regional fire-climate linkages at centennial to millennial scales (Swetnam et al. 1999).

During the Last Glacial to the early Holocene (20,000-10,000 cal. B.P.), Western Europe experienced major millennial-scale temperature changes and shortlived, high amplitude climate reversals (Walker 1995) as well as changes in seasonality (Wagner-Cremer and Lotter 2011). This period is the last time that Europe experienced rapid warming of similar magnitude and rate of change as predicted for the future. These climate variations triggered rapid vegetation changes in terms of structure, composition and distribution (Reille and Andrieu 1995; Jalut et al. 2010). Moreover, the human mode of subsistence at that time in southern Europe, i.e. hunting-gathering, implies minimal impact on the environment, and at least no detectable manipulation of fire for ecosystem management (Daniau et al. 2010). This period is thus particularly suitable for assessing the possible linkages between fire, climate and vegetation.

Palaeoecological studies dedicated to fire-climate relationships in Europe are increasingly numerous but few encompass the whole Late-Glacial period (e.g. Clark et al. 1989; Kaltenrieder et al. 2010) and are not dedicated to fire-climate linkages during this period. The present study, specifically focusing on Late-Glacial fire regimes, is a first attempt to investigate the response of fire activity to successive temperature oscillations, vegetation structure, and biomass (i.e. fuel) changes in South-western Europe.

In this paper, we derived Late-Glacial fire activity from two neighbouring lacustrine macrocharcoal records, Ech palaeolake and Lake Lourdes, located $3 \mathrm{~km}$ apart. To understand the effect of external forcings, we reconstructed summer $\mathrm{T}^{\circ}$ changes and vegetation dynamics from two independent proxies (chironomids and pollen, respectively). We then compared both palaeofire records with a chironomid-inferred summer air temperature reconstruction from Ech palaeolake (Millet et al. 2012). Given the current fire season in the Pyrenees, i.e. an anthropogenic one linked to pasture management in winter and a natural one in summer (July and August, Rius et al. 2011), a proxy for summer temperature was needed. We also discuss the role of vegetation type, structure and biomass availability using pollen analysis from Ech palaeolake and Lourdes (Reille and Andrieu 1995).

The main objectives of the paper are:

(i) To assess biomass burning response to high-amplitude, short-lived climate oscillations, both warming (e.g. the onset of the Late-Glacial Interstadial and the Younger Dryas-Holocene transition) and cooling (e.g. Interstadial cold reversals);

(ii) To assess the response of fire activity to millenniallong climatic patterns (e.g. the gradual cooling of the Interstadial and the Younger Dryas cold reversal);

(iii) To discuss biomass availability as a limiting factorare Late-Glacial fire regimes fuel-limited (i.e. primarily controlled by vegetation change) or droughtdriven?

\section{Study area}

The mountain chain of the Pyrenees stretches from the Atlantic Ocean to the Mediterranean Sea (Fig. 1). This intermediate geographical position implies the existence of a strong W-E climatic and ecological gradient throughout the chain from the Atlantic climate prevailing in the western part to the Mediterranean climate in the eastern zone. Both study sites are located in the central part of the chain, in the vicinity of Lourdes $\left(43^{\circ} 3^{\prime} 53^{\prime \prime} \mathrm{N}, 0^{\circ} 02^{\prime} 44^{\prime \prime} \mathrm{W}\right)$.

This area is characterised by a mountainous oceanic climate with a mean annual precipitation of 1,200 $\mathrm{mm}$. The mean annual $\mathrm{T}^{\circ}$ is $12.5^{\circ} \mathrm{C}$ (Mean summer $\mathrm{T}^{\circ}=19$ and mean winter $\mathrm{T}^{\circ}=6{ }^{\circ} \mathrm{C}$, meteorological data monitored at Lourdes between 1931 and 2006). The regional vegetation consists of Atlantic-type oak forest mainly dominated by Quercus (Q. robur and Q. pyrenaica) with Corylus and Betula. The north-facing slopes (up to $900 \mathrm{~m}$ a.s.l.) are covered by a mixed beech-oak forest (Fagus sylvatica), which is the dominant vegetation type of the bioclimatic hill stage in the area.

Ech palaeolake ( $710 \mathrm{~m}$ a.s.1.) is now a 5.3 ha peat bog (200 m wide and $280 \mathrm{~m}$ long) with a 100 ha catchment. Formerly it was a small glacial lake, located on a plateau dammed by a recessional moraine to the south and by a $200 \mathrm{~m}$ high south-facing calcareous slope to the north.

Lake Lourdes ( $430 \mathrm{~m}$ a.s.1.) is $44.8 \mathrm{ha}$ in area $(1 \mathrm{~km}$ long, $500 \mathrm{~m}$ wide) and is located in a small perched watershed (274 ha). There is no inlet feeding the lake, and a small outlet at its eastern shore.

\section{Materials and methods}

Coring and lithology

Ech palaeolake was cored with a Russian peat sampler $(10 \mathrm{~cm}$ in diameter) and 10 overlapping $1 \mathrm{~m}$-long sections were retrieved from two boreholes at the centre of the 
Fig. 1 Location of the study area in the Pyrenees (upper panel), location of the study sites in the Lourdes basin on a digital elevation model (lower left panel) and bathymetry of Lake Lourdes with the coring point (lower right panel). The coordinate system of the location map and the bathymetry is WGS 84 , while the elevation model has a metric scale

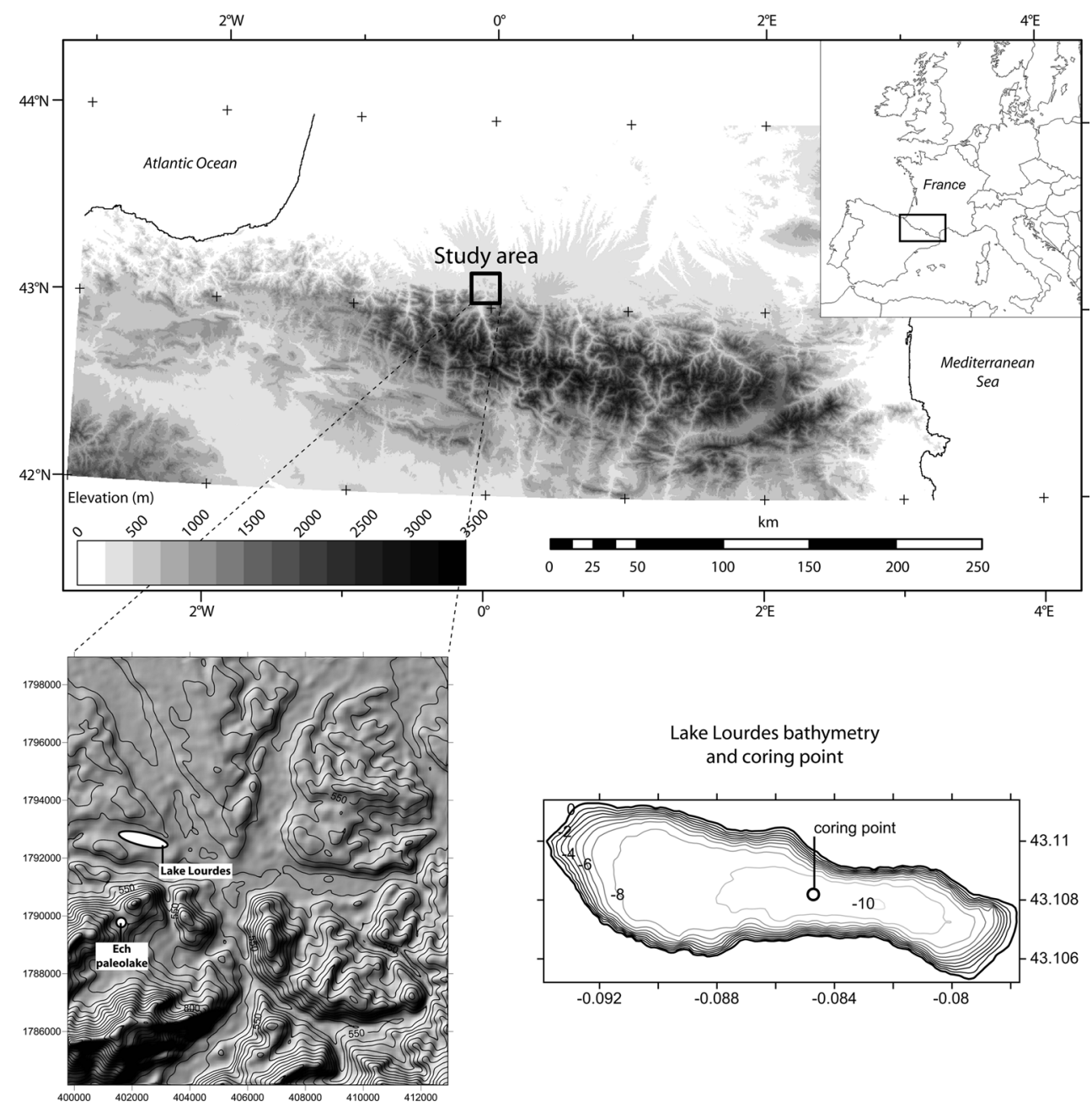

raised bog. Lake Lourdes was cored with an Uwitec gravity corer $(6.3 \mathrm{~cm}$ in diameter) and 10 overlapping $3 \mathrm{~m}$-long sections were retrieved from 3 boreholes at the deepest part of the lake (Fig. 1).

Composite cores of $5 \mathrm{~m}$ (Ech palaeolake) and $9 \mathrm{~m}$ (Lake Lourdes) were built from magnetic susceptibility and gamma density profiles acquired at high resolution $(5 \mathrm{~mm}$ intervals) using a Geotek Multi-Sensor Core Logger. Magnetic susceptibility and density are widely used proxies to estimate detrital inputs.

For Ech palaeolake, the lithological profile is typical of a lake progressively filled up by sediment and the subsequent development of a peat bog. Along the core, peat accumulation begins at $330 \mathrm{~cm}$ below the surface, overlying lacustrine deposits consisting of silt, clay and coarse organic remains in varying proportions.

The sediment profile from Lake Lourdes is typical of shallow and organic lakes, with a $7.7 \mathrm{~m}$-thick accumulation of brown organic gyttja, overlying silty deposits with organic remains in varying proportions.

\section{Chronology}

The chronology for this study is derived from a set of 13 AMS radiocarbon dates (Table 1). In Ech palaeolake 2 samples of terrestrial material and 5 samples of bulk sediment ( 7 in all) were AMS-dated. In Lake Lourdes, 6 dates were performed on charcoal and terrestrial macro-remains. These 13 AMS dates were calibrated to years before present (cal B.P.) with Calib 6.0.1 using the Intcal09 calibration curve (Reimer et al. 2009).

The chronology of Ech palaeolake has already been discussed by Millet et al. (2012). It was constrained with two palynostratigraphic estimated ages (Table 1; Fig. 2). Four of the 7 dates were found to be too old in reference to the regional palynostratigraphy, and were then not used to model depth-age relationship.

A robust and reproducible procedure of depth-age modelling was needed to ensure a reliable comparison between the two sedimentary records. In particular, confidence intervals for estimated ages were a prerequisite. 
Table 1 AMS-radiocarbon dates and material dated

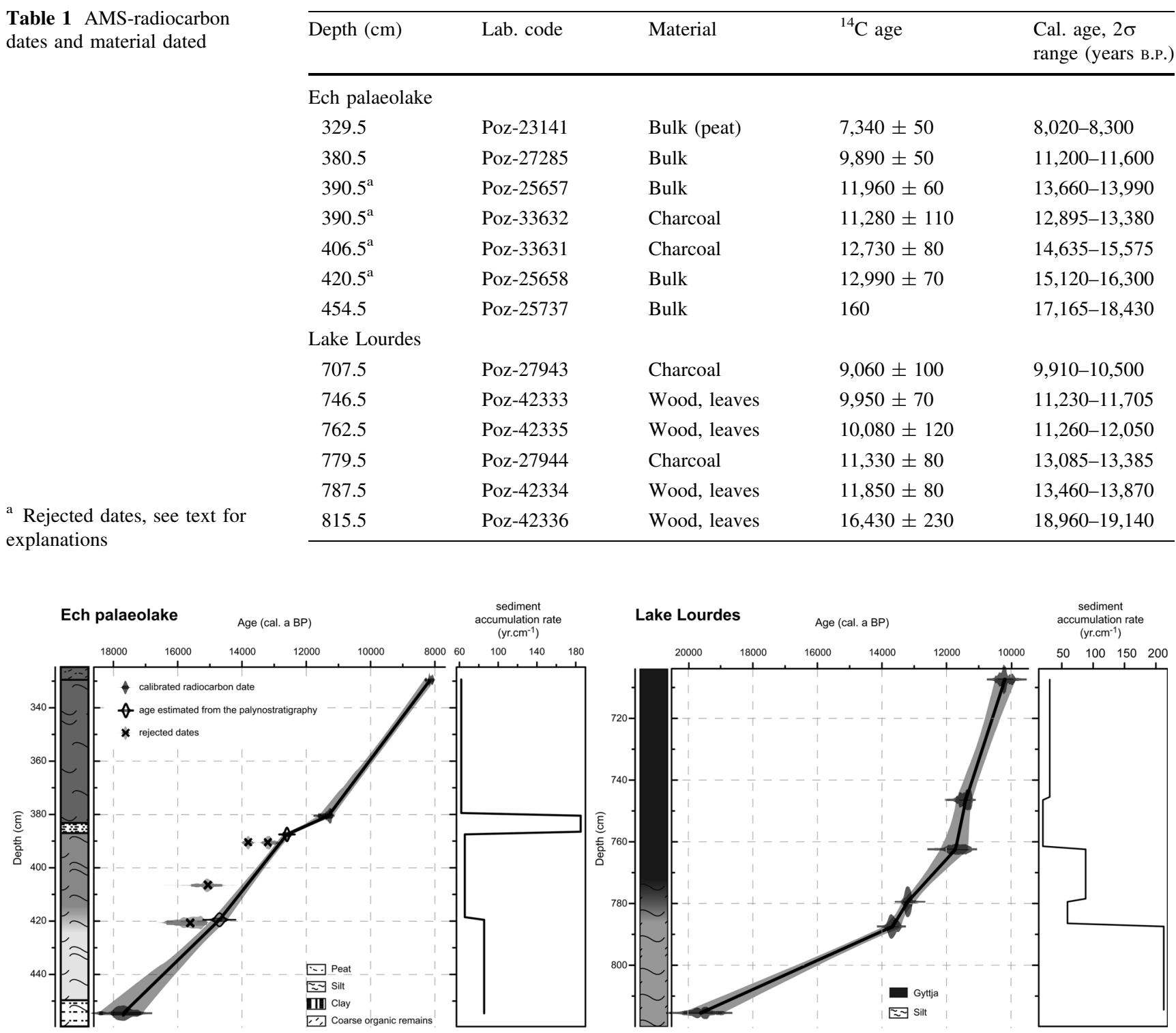

explanations

Fig. 2 Lithology, depth-age model and sediment accumulation rate (year $\mathrm{cm}^{-1}$ ) of Ech palaeolake and Lake Lourdes. See Sect. 3 for more details on the building of chronologies

Therefore, the depth-age model of Ech palaeolake was redrawn from Millet et al. (2012) using CLAM (Blaauw 2010), with the same modelling method (i.e. linear interpolation) in order to derive the same chronology.

The depth-age model for Lake Lourdes was built using the same method, as non-linear methods (such as cubic spline or polynomial regression) failed to model the rapid sedimentation changes of the Late-Glacial to the early Holocene.

Organic matter analyses

Loss-On-Ignition (LOI) was performed on Ech palaeolake wet samples taken contiguously at $1 \mathrm{~cm}$ intervals between
369 and $422 \mathrm{~cm}$ and at 3-7 $\mathrm{cm}$ intervals down to $476 \mathrm{~cm}$. 1.5-4 g (constant volume) of wet sediment was dried at $105^{\circ} \mathrm{C}$ overnight and then ignited at $550{ }^{\circ} \mathrm{C}$ for $4 \mathrm{~h}$ with the weight loss measured after each stage, in order to quantify the organic matter (OM) content (Heiri et al. 2001). LOI is expressed as a percentage of weight loss in dried sediment.

Total organic nitrogen and carbon concentrations were contiguously measured from Lake Lourdes with a Variomax CNS analyser (Elementar) using $\sim 200 \mathrm{mg}$ of dried material from $2 \mathrm{~cm}$-thick samples taken between 710 and $814 \mathrm{~cm} . \mathrm{CaCO}_{3}$ measurements performed with a Bernard calcimeter revealed a carbonate content $<1 \%$. Therefore sedimentary carbon is assumed to be organic ( $C_{\text {org }}$, Fig. 4$)$. 
The Carbon:Nitrogen ratio (C:N) is widely used to assess the abundance of terrestrial and aquatic components of OM (Meyers and Ishiwatari 1993).

Pollen analyses

Pollen analyses were performed on the Ech paleolake record. The whole sediment profile was sampled at $5 \mathrm{~cm}$ intervals (30 samples for the Late-Glacial part). Some additional levels ( 3 samples) were analysed between 380 and $390 \mathrm{~cm}$ within a sediment unit corresponding to the Younger Dryas. Standard methods involving $\mathrm{NaOH}$ $(10 \%), \mathrm{HCl}, \mathrm{HF}(30 \%)$ and acetolyis treatment $(5 \mathrm{~min})$ were applied for pollen preparation. The pollen preservation was good and concentrations were always sufficient to count over 450 terrestrial pollen grains per slide. Pollen percentages are based on the pollen sum of arboreal (AP) and non-arboreal (NAP) pollen grains, excluding Alnus, Cyperaceae, aquatic taxa and fern spores.

For Lake Lourdes we relied on Reille and Andrieu (1995) pollen analyses performed in the peat bog at the western shore of the lake.

Chironomid analysis and summer temperature inference

Chironomids were analysed in the Ech palaeolake record in 52 samples of $1 \mathrm{~cm}$ thickness, contiguously between 382 and $421 \mathrm{~cm}$ and at 3-7 cm intervals within sections 421-476 and $370-382 \mathrm{~cm}$. Head capsules were extracted from the sediment following the procedure described by Walker (2001). Chironomid-inferred July air temperatures were reconstructed using the chironomid-temperature transferfunction described by Heiri et al. (2011). This transferfunction is based on a modern calibration dataset from the Alpine and Norwegian region and Weighted AveragingPartial Least-Squares regression (WA-PLS; Ter Braak and Juggins 1993).

Further detailed methods of both chironomid analysis and chironomid-inferred July air temperatures of Ech palaeolake can be found in Millet et al. (2012).

Charcoal analysis and changepoint approach

At both Ech palaeolake and Lake Lourdes, contiguous $2.6 \mathrm{~cm}^{3}$ samples were retrieved using a cut needleless syringe at every $\mathrm{cm}$ of the core. The samples were soaked in a $10 \% \mathrm{NaOH}$ solution for $24 \mathrm{~h}$ to disaggregate organic silts, then in a $6 \% \mathrm{H}_{2} \mathrm{O}_{2}$ solution for the same time to bleach the remaining non-charcoal organic material and thus make charcoal identification easier (Rhodes 1998). Charred particles were isolated using wet sieving with a $150 \mu \mathrm{m}$ mesh. Charcoal Area Concentration (CHAC, $\mathrm{mm}^{2} \mathrm{~cm}^{-3}$ ) of charcoal particles was estimated under a binocular microscope at $50 \times$ magnification with a reticule grid of $10 \times 10$ squares of $62.5 \times 10^{-3} \mathrm{~mm}^{2}$ each. Charcoal concentration was expressed as Charcoal Accumulation Rate (CHAR, $\mathrm{mm}^{2} \mathrm{~cm}^{-2}$ year $^{-1}$ ) based on the sediment accumulation rate (year $\mathrm{cm}^{-1}$ ).

The mean sediment accumulation rate $(75$ and 90 year $\mathrm{cm}^{-1}$ for Ech palaeolake and Lake Lourdes respectively) precludes the decomposition of charcoal records for fire frequency calculation (Higuera et al. 2009). Each centimetric sample may aggregate several distinct local fire events or may contain charcoal secondary deposited from a previous fire (Whitlock and Millspaugh 1996). We thus needed an alternative means of checking if significant changes occur in fire activity (i.e. in the distribution of CHAR), with respect to climate and vegetation change. Usual methods include non-parametric tests such as MannWhitney (Rius et al. 2011). In this case, the boundaries of the chronological periods to be tested against each other have to be arbitrarily pre-determined. We thus chose to apply a changepoint approach which enables the detection of significant changepoints in time where observations follow one distribution up to that point and follow another one subsequently (Pezzatti et al. 2013). Among different detection methods, we chose to check both Ech and Lourdes charcoal records for significant changepoints in mean and variance. These were computed using the "changepoint package" (Killick and Eckley 2011) under the R open-source statistical environment (R Development Core Team 2011).

The aim is to detect the major changepoints for each record and check if they chronologically match the three major climate and vegetation changes of the $20,000-10,000$ cal. B.P. interval; (1) the Oldest Dryas-Late-Glacial transition, (2) the Younger Dryas and (3) the onset of the Holocene (Millet et al. 2012). We also used the method as a means of chronological control between the two records-for each detected changepoint there are $n$-possible estimated ages from $n$-iterations of the depth-age model (1,000 by default in CLAM). We computed a probability density function of these $n$-possible estimated ages at each changepoint. It was then possible to determine the probability that the two changepoints fell in the same time slice, i.e. if the response of fire activity to external forcing (climate and vegetation changes) occurred simultaneously in both records.

\section{Results and interpretation}

Climate and vegetation changes

The Ech palaeolake chironomid-inferred summer air temperature fits with other European temperature reconstructions as well as with the NGRIP $\delta^{18} \mathrm{O}$ (Millet et al. 2012). 
Fig. 3 Global palaeoclimate data (NGRIP $\delta^{18} \mathrm{O}, 50$ years, Lowe et al. 2008), local summer temperature (Chironomid inferred, Millet et al. 2012), and simplified percentage pollen diagram from Ech palaeolake

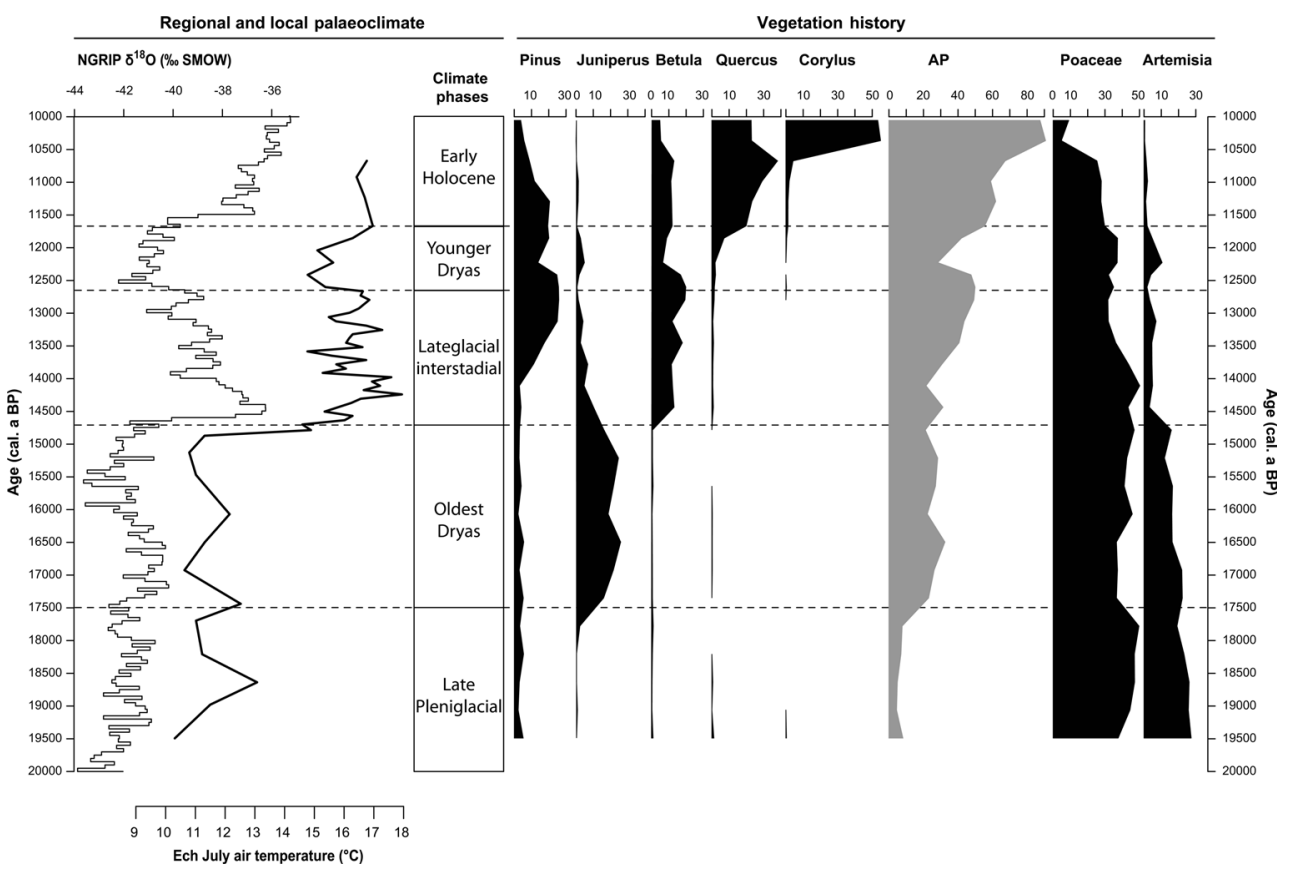

Consequently, we used these temperatures to define the local Late-Glacial climate event chronology (plotted in Figs. 3, 4, 5 and 6).

The Ech pollen record is typical for the Last Glacial to early Holocene vegetation succession in the Lourdes basin and in the Pyrenees (Reille and Andrieu 1995; Jalut et al. 2010).

Therefore, local climate and vegetation changes from the Last Glacial to the Holocene can be described as follows (Fig. 3):

- From 20,000 to 14,700 cal. B.P., i.e. the Late Pleniglacial and the Oldest Dryas, climate variability was low, with transient summer temperature variations between 10 and 13 and an average of $11.7^{\circ} \mathrm{C}$. Pollen percentages were strongly dominated by Poaceae (40-50\%) and Artemisia (15-25\%, Fig. 3), while the first rise of Arboreal Pollen percentages (hereafter referred to as AP) ca. 17,700 cal. B.P. is mainly due to an increase in Juniperus percentages. These vegetation patterns are consistent with steppe-dominated vegetation reconstructed in the Pyrenees before the onset of the Bølling (14,700 cal. B.P., Jalut et al. 1992). Woody biomass is thus almost non-existent as Pinus percentages $(<10 \%)$ and isolated occurrences of Betula and Quercus probably reflect long-distance transport from refugium areas (Jalut et al. 1992).

- At the Oldest Dryas-Late-glacial Interstadial transition (ca. 15,000-14,700 cal. B.P.), summer temperatures abruptly increased, from ca. 11 to $16{ }^{\circ} \mathrm{C}$ (Fig. 3). Internal climate variability was relatively high throughout the Interstadial $(14,700-12,700 \mathrm{cal}$. B.P.). First, temperature continued to increase and reached $17 / 18{ }^{\circ} \mathrm{C}$ between ca. $14,200-14,000$ cal. B.P. Then the following period was characterised by a gradual cooling pattern (ca. $-1{ }^{\circ} \mathrm{C}$ on average) interrupted by 3 short-lived cold events of $1.5^{\circ} \mathrm{C}$ magnitude ca. 13,900, 13,600 and 13,100 cal. B.P. (Fig. 3). As suggested by Millet et al. (2012), these cold events may respectively correspond to the GI-1d, GI- $1 \mathrm{c}$ and GI- $1 \mathrm{~b}$ in the Greenland event stratigraphy (Lowe et al. 2008).

Pollen assemblages were marked by an increase of Betula (up to $15 \%$ ) and a converse drop of Juniperus and Artemisia (Fig. 3) ca. 14,700 cal. B.P. The decrease of Poaceae was delayed to ca. 14,000 cal. B.P. while Pinus percentages increased (up to $25 \%$ ). AP \% progressively rose from $20 \%$ ca. 14,700 to $50 \%$ ca. 12,700 cal. в.P. These changes in pollen assemblages can be related to the development of birch-dominated wooded steppe communities during the Bølling and to Pinus establishment at the onset of the Allerød in the area (Jalut et al. 1992).

- At the Late-Glacial Interstadial-Younger Dryas transition $(12,700 \mathrm{cal}$. в.Р.) summer temperature suddenly shifted from ca. $16.8{ }^{\circ} \mathrm{C}$ to values ranging from 14.8 to $15.6{ }^{\circ} \mathrm{C}$ (mean $=15.2{ }^{\circ} \mathrm{C}$ ) during the Younger Dryas. AP decreased to $25 \%$ (Fig. 3). Woody taxa (Pinus and Betula) decreased by $10 \%$ while Juniperus, Artemisia and Poaceae rose. This shift to steppe communities is the signature of the Younger Dryas at the regional scale (Aubert et al. 2004; Jalut et al. 1992; Reille and Andrieu 1995).The progressive increase of summer temperature during the second half of the Younger Dryas (from ca. 12,000 cal. в.P.) was accompanied by 
the reverse vegetation trend (Fig. 3) with a slight increase of Quercus percentages, which marks the beginning of the establishment of oak-birch hardwood forests.

- Finally, the onset of the Holocene (11,700 cal. B.P.) was characterised by increasing summer temperature reaching ca. $17^{\circ} \mathrm{C}$, i.e. less than the $19^{\circ} \mathrm{C}$ current value. The Ech palaeolake temperature record does not extend beyond ca. 10,700 cal. B.P., but its good correspondence with the NGRIP (Fig. 3) permits the assumption of increasing summer temperature throughout the early Holocene (11,700-10,000 cal. B.P.) in the area. This warming trend has already been highlighted from vegetation (Reille and Andrieu 1995; Jalut et al. 1992) and fire history (Rius et al. 2011). During this period, vegetation succession was characterised by an increase of Quercus percentages (up to $40 \%$ ), followed by an abrupt rise of Corylus (>50\%) while Betula, Pinus and Poaceae decreased. The successive establishment of oak and hazel is typical for the onset of the Holocene at the local (Reille and Andrieu 1995) and southern Europe scales (Finsinger et al. 2006). Oak-hazel forests were then dominant with AP percentages increasing from $55 \%$ ca. 17,000 to $90 \%$ ca. 10,000 cal. B.P.
Lithology, geophysics measurements and organic matter analyses

The Ech palaeolake record was characterised by a succession of 6 clearly distinct sediment units (Millet et al. 2012 and Fig. 2):

Inorganic proglacial blue clay $(500-485 \mathrm{~cm})$;

Light grey silty-clay $(485-450 \mathrm{~cm})$;

Grey-brown silt $(450-420 \mathrm{~cm})$;

Brown organic silt (420-387 cm);

A thin layer of grey silty clay $(387-383 \mathrm{~cm})$;

Dark-brown silt $(383-360 \mathrm{~cm})$.

The Lake Lourdes record shows less contrasting changes in lithofacies (Fig. 2) and cannot be depicted with clearly distinct sediment units. The sediment accumulation was characterised by brown organic gyttja (707-772 cm upwards) and grey-brown silts $(772-815 \mathrm{~cm})$.

Geophysics measurements (magnetic susceptibility, hereafter denoted MS, and gamma density) and OM analyses give evidence of comparable results between sites (Fig. 4) that can be described as follows:

- The Late Pleniglacial and the Oldest Dryas (20,000-14,700 cal. B.P.) were characterised in both
Fig. 4 Left-hand panels: OM (LOI $550{ }^{\circ} \mathrm{C}, \%$ ), Gamma density and Magnetic susceptibility (dashed line) from Ech palaeolake. Right-hand panels: organic carbon $\left(\mathrm{C}_{\mathrm{org}}, \%\right)$, Carbon/Nitrogen ratio (dashed line), Gamma density and Magnetic susceptibility (dashed line) from Lake Lourdes. The sediment data for both lakes are plotted against the regional climate event chronology (middle panel)
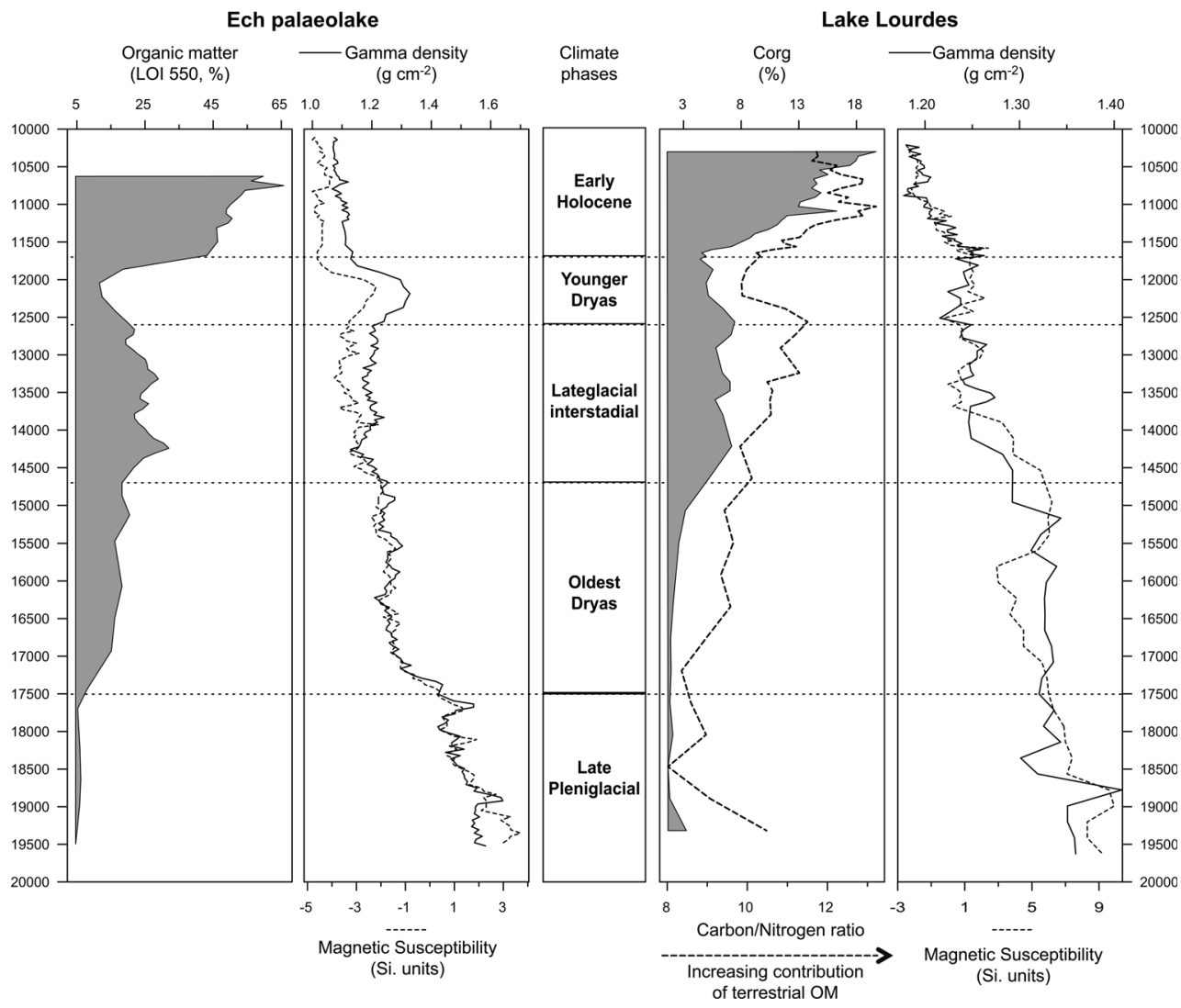
lakes by high but decreasing values of MS and density and on the other hand by progressively increasing content of OM. Although the $\mathrm{C}: \mathrm{N}$ ratio (Fig. 4) globally indicates that the whole record was dominated by $\mathrm{OM}$ of lacustrine origin (values between 8 and 13), the contribution of terrestrial OM slightly increased in Lake Lourdes during this phase.

- The Late-Glacial Interstadial (14,700-12,700 cal. B.P.) was characterised by a stabilization (Ech) or decrease before stabilization (Lourdes) in MS and density while $\mathrm{OM}$ content and $\mathrm{C}: \mathrm{N}$ ratio increased.

- The Younger Dryas (12,700-11,700 cal. B.P., Fig. 4) shows a decrease in OM content and in terrestrial OM contribution while MS and density globally increased. This increase was less marked in Lake Lourdes.

- The beginning of the Holocene was characterised by an increase of $\mathrm{OM}$ content and $\mathrm{C}: \mathrm{N}$ ratio to their highest values while both MS and density measurements decreased.

Charcoal accumulation rates and fire history

Figure 5 presents the charcoal data from Ech palaeolake and Lake Lourdes.

CHAR values ranged from 0 to $0.8($ mean $=0.15)$ for Ech palaeolake and from 0 to $3.9 \mathrm{~mm}^{2} \mathrm{~cm}^{-2}$ year (mean $=0.85$ ) for Lake Lourdes. Correlation between charcoal counts and area was high, with an $\mathrm{r}^{2}$ of 0.94 and $0.96(p<0.05)$ for Ech and Lourdes records respectively.

Due to rapid sedimentation change, Ech best documents the Late-Glacial Interstadial, while the Younger Dryas and the early Holocene are better resolved within the Lake Lourdes record.

The charcoal-derived fire activity of both sites could be summarized as follows:

- From 20,000 to 14,700 cal. B.P., i.e. the Late Pleniglacial and the Oldest Dryas, CHAR was nil (Fig. 5) and there was no detectable fire activity

- At the Oldest Dryas-Late-Glacial transition (ca. 15,000-14,700 cal. B.P.), an increase in CHAR was recorded at both sites. In Ech palaeolake, CHAR exhibited a progressive increase until 13,400 cal. B.P. interrupted by transient decreases ca. 13,900-13,750 and 13,700-13,400 cal. B.P. Despite a peak ca. 13,300 cal. B.P. (Fig. 5), CHAR values shows a progressive decrease from 13,400 cal. B.P. onwards with a marked low phase between 13,300 and 13,000 cal. B.P. At Lake Lourdes, CHAR progressively increased from 14,700 to 13,600 cal. B.P., remaining at low values with no internal variability in a phase where the sediment accumulation rate was the highest (200 years $\mathrm{cm}^{-1}$ ) of the record. A steady high phase was recorded between 13,600 and
13,300 cal. B.P., followed by a marked low phase between 13,300 and 12,900 cal. B.P.

- The end of the Late-Glacial Interstadial was characterised by an increase of CHAR values between 13,100 and $12,700 \mathrm{cal}$. B.P. at Ech palaeolake and Lake Lourdes. This increase was then followed by a marked decrease and steady low values, comparable to those of the Oldest Dryas, until 12,000 and 11,800 cal. B.P. for Ech and Lourdes respectively (Fig. 5). The Younger Dryas millennial-long cold reversal is thus characterised by a drop in recorded fire activity followed by an increase during its second half (Ech palaeolake) or at the transition with the Holocene (Lake Lourdes).

- At the end of the Younger Dryas, both sites recorded abrupt and high amplitude increases in CHAR values. In Ech palaeolake there was a two-step increase (ca. 12,000 and 11,250 cal. B.P.) that corresponds to an abrupt change in modelled sediment accumulation rate (from 185 to 60 years $\mathrm{cm}^{-1}$; Figs. 2, 5). Lake Lourdes shows a onestep increase from 11,800 to 11,400 cal. B.P., where CHAR reached its highest values of the record and of the

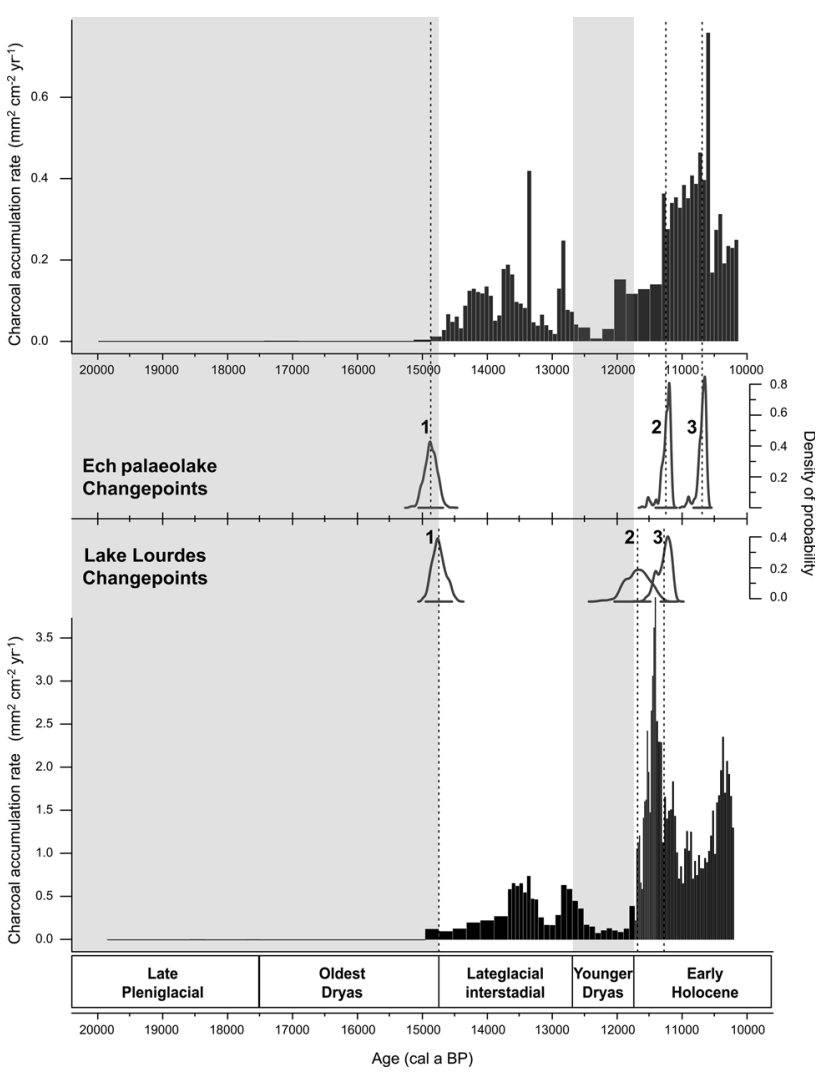

Fig. 5 Bar plots of Charcoal Accumulation Rate (CHAR, $\mathrm{mm}^{2} \mathrm{~cm}^{-2}$ year $^{-1}$ ) from Ech palaeolake and Lake Lourdes (top and bottom panels, respectively). The width of the bars corresponds to the time span of each analysed sample. Significant changepoints are plotted (vertical dotted lines) with their chronological uncertainties (bold grey lines, see Sect. 3 for details) 
whole Holocene (Rius et al. 2011). In Ech palaeolake, the early-Holocene (until 10,000 cal. B.P.) is then characterised by a progressive increase in CHAR peaking ca 10,500 cal. B.P., followed by a decrease (Fig. 5) even if values remained higher compared to the Interstadial and the Younger Dryas. In Lake Lourdes, CHAR values abruptly decreased from 11,500 to 11,000 cal. B.P. and rose again from this point.

Significant changepoints in mean and variance of CHAR (Fig. 5) were detected at 14,850 $( \pm 185), 11,250( \pm 150)$ and $10,700( \pm 125)$ cal. B.P. for Ech palaeolake, and at 14,700 $( \pm 205), 11,700( \pm 350)$ and $11,300( \pm 215)$ cal. B.P. for Lake Lourdes. The onset of the Interstadial was detected ca. 14,700 cal. B.P. as probability of both changepoints totally overlaps (Fig. 5). The Younger Dryas-Holocene transition was detected as a significant changepoint only in Lake Lourdes whereas in Ech palaeolake only the second part of the two-step increase in CHAR was detected (ca. 11,200 cal. B.P.). Finally, the method failed to detect any significant changepoint at the Interstadial-Younger Dryas transition in both records.

\section{Discussion}

Chronology of Late-Glacial climate events

The reliability of the Ech palaeolake record chronology has already been discussed and assessed with respect to AMS dates, sediment properties, regional pollen stratigraphy and temperature reconstruction (Millet et al. 2012). However, the accuracy of the Lake Lourdes chronology as a Late-Glacial environmental archive is not established yet, even if the neighbouring peat bogs show consistent vegetation patterns with Ech (Table 2; Reille and Andrieu 1995). As we do not have direct pollen analyses from the Lake Lourdes record, we rely on sediment properties (OM analyses and geophysics measurements) of both sites to discuss the Late-Glacial climate events chronology (Table 2).

First, the sediment response to climate events (Fig. 4) is clearly visible in the Ech palaeolake record. OM content and detrital inputs (MS and density) are anti-correlated and show cold periods to be characterised by high detrital inputs and low OM content (Oldest and Younger Dryas) with the converse pattern for warmer phases (Interstadial and early Holocene). This response also depends on the vegetation and in particular on the development of woody stands, which partly conditions pedogenesis, stabilizes soils and reduces detrital input (Zolitschka 1998; Vanniere et al. 2004; Magny et al. 2006a). This relationship is highlighted by the correlation between $\mathrm{AP}$ and $\mathrm{OM} \%$ in the Ech record (Fig. 4). Such an anti-correlation pattern is also detectable in Lake

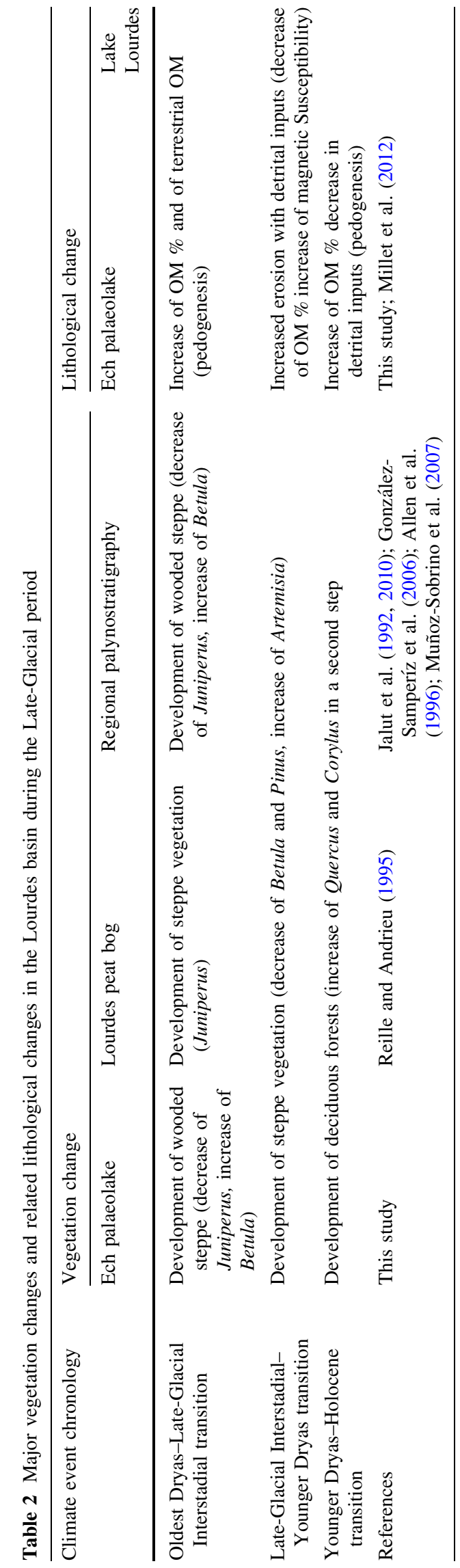


Lourdes, but with a less marked detrital response to climate and vegetation changes (Fig. 4), particularly for the Younger Dryas. This difference may be explained by the lake/watershed area ratio: Ech palaeolake was small (ca. 5 ha) with a steeply sloping watershed of ca 100 ha while Lake Lourdes is a large lake (44.8 ha) with a small gently sloping watershed (274 ha). The Lake Lourdes watershed thus has small amounts of erodible material (both terrestrial OM and detrital) that can less easily be mobilized by gravity. Given the size of the lake it may explain why the detrital/OM response to climate and vegetation changes is diluted and less perceptible. It may also explain the abrupt sediment response in Ech palaeolake to the onset of the Holocene, and the progressive response in Lake Lourdes (Fig. 4). However, the good consistency of this millennial-long pattern in sediment response between both sites supports the overall reliability of Lake Lourdes chronology (Fig. 2).

It is thus possible to compare fire activity between sites and to discuss the response of fire regime to climate and vegetation changes at the millennial scale. The onset of the Late-Glacial Interstadial occurred simultaneously in both records as emphasised by the changepoints approach (Figs. 5, 6). GI-1b and the onset of the Younger Dryas are also simultaneously recorded in fire activity (Fig. 5), even if these are not highlighted as a significant change in charcoal accumulation (Fig. 5). The other changepoints are located at the beginning or within the first millennium of the Holocene, and are partly overlapping, with respect to changepoint no. 2 (Fig. 5). The two-step increase in CHAR in Ech paleolake explains why changepoint no. 2 is detected ca. 11,250 cal. B.P., while at Lake Lourdes it is at 11,700 cal. B.P. matching the onset of the Holocene in the area (Jalut et al. 1992; Millet et al. 2012; Rius et al. 2012). However, changepoints highlight the overall good consistency of fire history between the two records and establish the beginning of the Interstadial and the early Holocene as key phases for fire regimes in the area.

Finally, the potential influence of sedimentary dynamics on charcoal accumulation, i.e. transport of secondary charred particles by runoff and/or erosion (Whitlock and Millspaugh 1996) can be partly ruled out. Indeed, the period with highest detrital inputs (OD and YD, Fig. 6) did not lead to increased CHAR.

Last Glacial to early Holocene fire-climate linkages and effects of change in vegetation type

\section{Late Pleniglacial and Oldest Dryas (>14,700 cal. B.P.)}

The absence of fire activity during this period can be explained by low summer temperature $\left(11.7{ }^{\circ} \mathrm{C}\right.$ in average $)$ which prevents the development of woody vegetation. Low summer temperatures, with probably longer-than-today snow periods combined with steppe vegetation probably resulted in discontinuous and wet material that totally prevented fire ignition and spread (Briles et al. 2012). However, the absence of any charcoal accumulation also underlines the crucial role of woody biomass as fuel. Indeed, other studies from Europe and elsewhere for that time period shows that low fire activity can be sustained by woody biomass e.g. with $20 \%$ of Quercus in a refugium area (Kaltenrieder et al. 2010) or with Pinus at $20 \%$ in a high montane area (Briles et al. 2012).

\section{Late-Glacial Interstadial (14,700-12,700 cal. в.P.)}

Synchronous slight increases in fire activity are recorded ca. 14,700 cal. B.P. in both sites.

Abrupt summer temperature change $\left(7^{\circ} \mathrm{C}\right)$ and local vegetation that shifted from steppe to Betula-wooded steppe are both more favourable to fire occurrences than the conditions of the previous period. Warmer summer, probably combined with modified seasonality with earlier spring onset (Wagner-Cremer and Lotter 2011) may have led to earlier snowmelt. These conditions are known to lengthen the fire season and increase fire frequency in contemporary environments (Westerling et al. 2006).

This enhanced fire activity from 14,700 cal. B.P. onwards is typical of the onset of the Late-Glacial interstadial at both global and continental scales (Power et al. 2008; Marlon et al. 2009). Fire regimes in the Pyrenees also follow the regional trend inferred from marine cores (Daniau et al. 2009) that emphasised this highly contrasted response between Stadials and Interstadials.

However, in contrast to the amplitude of climate change, the response of the fire regime in the area remains limited as underlined by CHAR values that remain far below the Holocene levels (Fig. 6). The progressive increase in fire activity until ca. 13,500 cal. B.P. corresponds to increasing summer $\mathrm{T}^{\circ}$ (Fig. 6) but there is no correspondence between the gradual cooling trend during the Interstadial and fire activity. This temperature pattern is attenuated at the local scale $\left(-1{ }^{\circ} \mathrm{C}\right)$ compared to Greenland (Lowe et al. 2008). Therefore, this decrease in summer $\mathrm{T}^{\circ}$ is too weak to trigger a negative response in fire activity which appears tied to vegetation dynamics, i.e. the increasing importance of birch and more particularly that of pine in local vegetation (Fig. 3). This highly flammable, fire-adapted taxon (Higuera et al. 2009) probably promoted higher landscape flammability.

The three cold reversals of the Interstadial (GI-1d, $c$ and b) are recorded in summer $\mathrm{T}^{\circ}$ inference (Fig. 6) but were not detected in the $\%$ pollen record (Fig. 3). The sensitivity of fire regime to such short-lived and low amplitude $\left(1.5^{\circ} \mathrm{C}\right)$ cold oscillations is difficult to assess, in particular 


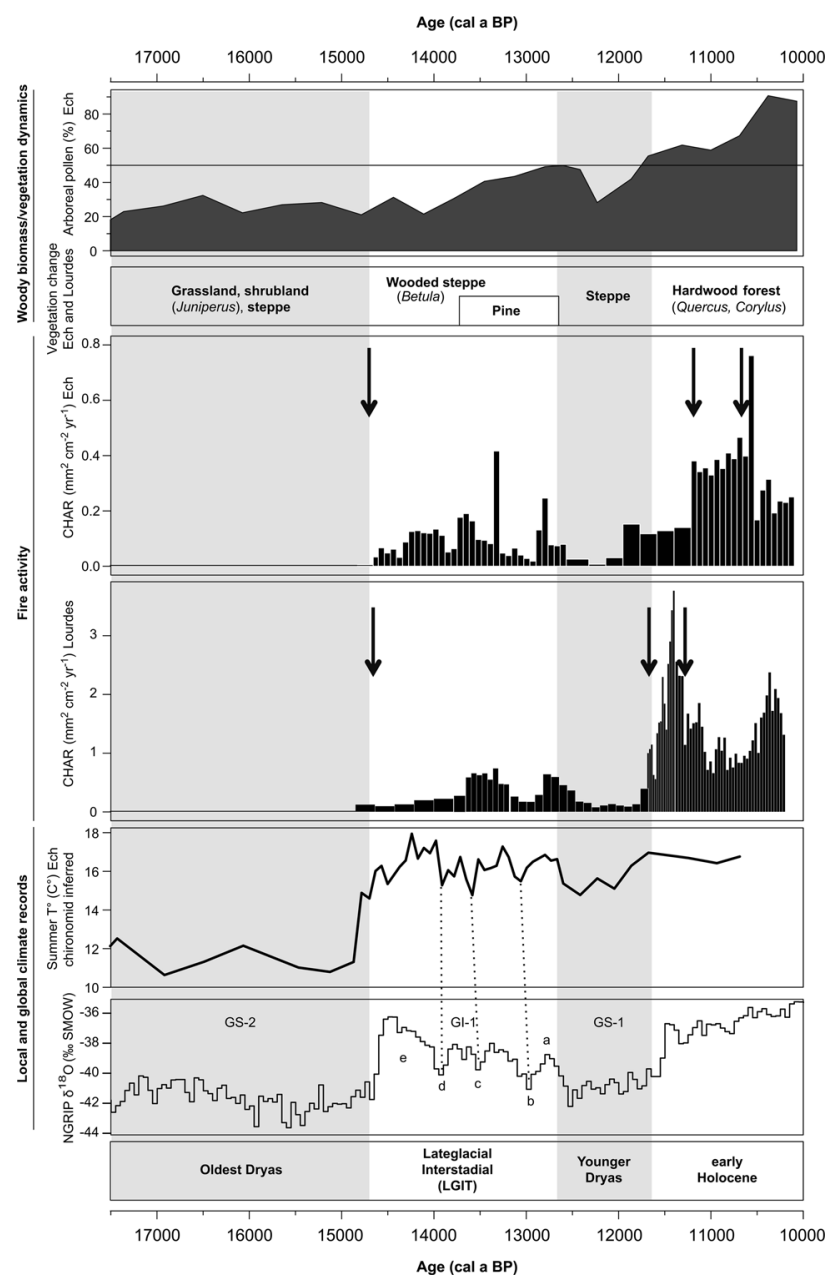

Fig. 6 Arboreal pollen $\%$ from Ech palaeolake and regional vegetation dynamics, fire activity (CHAR from Ech palaeolake and Lake Lourdes, black arrows indicate the main changepoints), plotted against local summer temperature inference (Millet et al. 2012) and global palaeoclimate record (NGRIP $\delta^{18} \mathrm{O}, 50$ years, Lowe et al. 2008)

when records have a multi-decadal resolution (Figs. 2, 5). The difference in temporal resolution may also explain why these short-lived cold events are better recorded in the Ech paleolake than in the Lake Lourdes record. In fact, none are detected as significant changepoints in charcoal accumulation (Fig. 5). The slight drop in fire activity ca. 13,800 cal. B.P. (Figs. 5, 6) cannot be related to the GI-1d because it is a 2-sample drop recorded only in Ech palaeolake. On the contrary, the cold event corresponding to GI$1 \mathrm{~b}$ (Fig. 6) is clearly evidenced by a fire activity decrease in both records between 13,300 and 12,900 cal. B.P. This negative response does not seem to depend on vegetation changes that could reduce fuel availability since there are no significant changes in dominant woody taxa (Pinus and Betula, Figs. 3, 6). This decrease in fire activity may be explained by the duration of this cold reversal, which is long enough to trigger a perceptible response in fire regime given the multi-decadal resolution of both records.

The last part of the Interstadial is characterised by a short-lived warming (Fig. 3) with a corresponding increase in fire activity (Fig. 6). Fire regime response to such a rapid and low amplitude warming has been recorded in northern America (Marlon et al. 2009) and in Europe (Van der Hammen and Van Geel 2008). These studies hypothesized that the rapid and abrupt cooling of the GI-1b triggered increased mortality in woody stands that would have added to the available fuel and facilitated an increase in fire in the following warming phase. This hypothesis, as yet the most likely, is difficult to demonstrate in our result for two reasons. Firstly this mechanism should also trigger the same response following the two other Interstadial cold reversals (GI-1d and c, Fig. 6), which is obviously not the case. Secondly, no decrease in woody stands can be inferred from the pollen data (AP \% are at their maximum for the Interstadial). Therefore, without better-resolved data it is difficult in the present study to assess fire-climate linkages during this short warming phase.

\section{Younger Dryas (12,700-11,700 cal. B.P.)}

During the Younger Dryas, fire activity markedly decreased during about a millennium, as shown by the lowest CHAR levels of the record, comparable to those of the very beginning of the Interstadial (Figs. 5, 6). Cool summers $\left(2{ }^{\circ} \mathrm{C}\right.$ lower on average, Fig. 6) were probably responsible for unfavourable conditions for fire ignition and spread, but it also appears that fuel availability and vegetation structure played a large role. Indeed, pollen diagrams (both this study and Reille and Andrieu 1995) indicate a shift to steppe-like communities. Such a shift may have promoted less dense forests, providing spatial discontinuity of combustible material. This interpretation is supported by sedimentological proxies that show evidence for higher erosion, probably due to scattered forest cover and thus soil destabilization (Magny et al. 2006a).

The end of the Younger Dryas, which is characterised by a warming (Fig. 6, Lotter et al. 1992; Heiri and Millet 2005), probably saw increased summer drought as has been recorded elsewhere in southern Europe (Magny et al. 2006b). Combined with the recovery of woody stands, these changes likely caused a longer fire season and slightly increased fire activity as shown by the pre-Holocene CHAR augmentation, which is less clearly recorded in Lake Lourdes than in the Ech paleolake record (Figs. 5, 6).

Early Holocene $(<11,700$ cal. B.P. $)$

Fire regime change at the onset of the Holocene is the most important of the whole record as highlighted by two out of 
three changepoints detected in each record within the first millenium of the period (Fig. 6). CHAR reaches unprecedented level. Summer $\mathrm{T}^{\circ}$ reaching $17{ }^{\circ} \mathrm{C}$ (Berger and Loutre 1991) may have also led to increased summer drought. However, compared to the weak amplitude of increased fire activity at the onset of the Interstadial, triggered by a $7{ }^{\circ} \mathrm{C}$ summer $\mathrm{T}^{\circ}$ increase, climate change alone cannot account for this response of fire activity. These contrasting responses clearly evidence that during the Late-Glacial, vegetation was a limiting factor despite increasingly favourable climate conditions. At the onset of the Holocene, summer $\mathrm{T}^{\circ}$ were not higher in average than during the Interstadial, but the development of Oak-Hazel forests probably increased fuel availability (Fig. 6). In other words, woody biomass may have exceeded a threshold above which it no longer represented a limiting factor for fire ignition and spread. Combined with increased drought and summer $\mathrm{T}^{\circ}$, the vegetation provided dense continuous dry fuel in comparison with the more scattered vegetation of the Late-Glacial. Although deciduous forests (oak woodlands), are usually known to be less flammable than coniferous forests or shrublands in southern Europe (Fernandes et al. 2010), fire regimes were so fuel-limited during the Late-Glacial that the rapid settlement of oak in the northern Pyrenees may have actually increased landscape flammability. The establishment of Corylus woodlands $(10,500$ cal. B.P.) might also have played a role in this enhanced fire activity. Frequent fires probably favoured its rapid settlement (Finsinger et al. 2006) and palaeorecords show it is a fire-enhanced taxon (Tinner et al. 2000). In return, it might have promoted higher fire activity; in the Pyrenees Corylus-dominated pollen assemblages are often associated with high fire frequencies (Rius et al. 2009, 2011). However, without further investigation it is impossible to pinpoint the potential feedbacks between fire, climate and this vegetation type, which has no present-day analogue (Finsinger et al. 2006; Ralska-Jasiewiczowa et al. 2003).

Finally, if human influence has been discarded for the Palaeolithic period (Daniau et al. 2010), one might point that this early Holocene increase in fire activity is synchronous with the commonly accepted transition from the Paleolithic to the Mesolithic period ca. 11,700 cal. B.P. (Valdeyron 2008). Several studies concluded that fire was increasingly used by Mesolithic people for forest management (Mason 2000) and attracting game (Innes and Blackford 2003). In the northern Pyrenees, the examination of current paleoecological and archaeological data (Bahn 1984; Valdeyron 2008) shows that most Mesolithic sites have radiocarbon dates more recent than ca. 10,500 cal. B.P. (Barbaza and Lacombe 2005; Briois and Vacquer 2009), which does not match the fire regime transition. Besides, little is known about Mesolithic demography, but available studies point to a social re-organisation towards smaller groups with a more individual subsistence strategy
(Ghesquière and Marchand 2010). Finally, this re-organisation probably resulted in a more scattered environmental impact (Valdeyron 2008). These three arguments combined with the overall close response of fire regime to climate and vegetation changes do not support the hypothesis of such Mesolithic forest management in the area. In other words, it seems unlikely that human impact drove fire regimes out of their range of natural variability at that time.

\section{Conclusion}

This paper presents the first comparison of fire activity with quantified palaeoclimate for the Late-Glacial in the Pyrenees. The absence of sedimentary bias and the consistency of both records with climate and vegetation changes enabled us to assess biomass-burning response to high amplitude climate and vegetation changes.

The main results are as follows:

(1) Sedimentary charcoal is a highly climate-sensitive proxy for detecting Late-Glacial climate events in temperate areas, even if the role of external forcing factors (climate and vegetation) should be examined on a case-by-case basis.

(2) At the millennial scale, major cold periods are characterised by negligible or low fire activity (Oldest and Younger Dryas). The impact of short-lived cold excursions during the Late-Glacial Interstadial is more difficult to assess. Although cold periods are not detected as significant changepoints in CHAR, the response of fire regime to cold phases is much more marked than the vegetation response, in particular for the Younger Dryas.

(3) The onset of the Late-Glacial Interstadial $(14,700$ cal. B.P.) is highlighted as a significant changepoint in fire activity. High amplitude warming provoked a blackand-white response of fire regime: no fire at all before 14,700 cal. B.P., progressively increasing fire activity thereafter. But fire activity remains rather weak with respect to the amplitude of climate change. The second main changepoint in fire regime is the onset of the Holocene $(11,700 \mathrm{cal}$. B.P.). It was probably driven by warming, increased summer drought and by a threshold effect in fuel availability.

(4) Climate is the primary driver of fire regimes and vegetation acts as a secondary modulating factor: our results clearly show the transition from a fuel-limited fire regime during the Late-Glacial to a summerdrought driven one during the early Holocene. In the temperate Pyrenean environment, vegetation mediated the impact of high amplitude, abrupt LateGlacial climate changes on fire regimes. Surprisingly, 
the establishment of deciduous woodlands at the onset of the Holocene promoted higher fire activity than today.

(5) Finally, these results suggest that evaluating the impact of climate change, both past and present, on fire regime demands a careful examination of the contribution of vegetation dynamics and fuel build-up (both natural and human-induced) to landscape flammability.

Acknowledgments This study was funded by the ANPYR research program (FEDER/Western Pyrenees National Park) and the Laboratoire Chrono-Environnement (CNRS, Université de Franche-Comté). The authors express their sincere thanks to Michel Magny and Nicolas Valdeyron for helpful comments on the manuscript, and to Michael Coughlan for English editing.

\section{References}

Allen JRM, Huntley B, Watts WA (1996) The vegetation and climate of northwest Iberia over the last 14000 year. J Quat Sci $11: 125-147$

Aubert S, Belet JM, Bouchette A, Otto T, Dedoubat JJ, Fontugne M, Jalut G (2004) Dynamique tardiglaciaire et holocène de la végétation à l'étage montagnard dans les Pyrénées Centrales. CR Biol 327:381-388

Bahn PG (1984) Pyrenean prehistory: a palaeoeconomic survey of the French sites. Aris \& Phillips Ltd, Warminster

Barbaza M, Lacombe S (2005) L'Azilien des Pyrénées: une culture originale. In: Jaubert J, Barbaza M (eds) Territoires, déplacements, mobilité, échanges durant la Préhistoire: Terres et Hommes du Sud. CTHS, p 421-428

Berger A, Loutre MF (1991) Insolation values for the climate of the last 10,000,000 years. Quat Sci Rev 10:297-317

Bergeron Y, Cyr D, Girardin MP, Carcaillet C (2010) Will climate change drive 21 st century burn rates in Canadian boreal forest outside of its natural variability: collating global climate model experiments with sedimentary charcoal data. Int J Wildland Fire 19:1,127-1,139

Blaauw M (2010) Methods and code for 'classical' age-modelling of radiocarbon sequences. Quat Geochronol 5:512-518

Briles CE, Whitlock C, Meltzer DJ (2012) Last Glacial-interglacial environments in the southern Rocky Mountains, USA and implications for Younger Dryas-age human occupation. Quat Res 77:96-103

Briois F, Vacquer J (2009) L'abri de Buholoup. De l'Épipaléolithique au Néolithique ancien dans le piedmont central des Pyrénées. De Méditerranée et d'ailleurs, mélanges offerts à J. Guilaine. Archives d'Ecologie Préhistorique 141-150

Clark JS, Merkt J, Muller H (1989) Post-glacial fire, vegetation, and human history on the northern alpine forelands, south-western germany. J Ecol 77:897-925

Daniau A.-L, Goni MFS, Duprat J (2009) Last Glacial fire regime variability in western France inferred from microcharcoal preserved in core MD04-2845, Bay of Biscay. Quat Res 71:385-396

Daniau A.-L, d'Errico F, Goñi MFS (2010) Testing the hypothesis of fire use for ecosystem management by Neanderthal and upper palaeolithic modern human populations. PLoS ONE 5(2):e9157. doi:10.1371/journal.pone.0009157

Fernandes PM, Luz A, Loureiro C (2010) Changes in wildfire severity from maritime pine woodland to contiguous forest types in the mountains of northwestern Portugal. For Ecol Manag 260:883-892

Finsinger W, Tinner W, Van der Knaap WO, Ammann B (2006) The expansion of hazel (Corylus avellana L.) in the Southern Alps: a key for understanding its early Holocene history in Europe? Quat Sci Rev 25:612-631

Flannigan MD, Krawchuk MA, De Groot WJ, Wotton BM, Gowman LM (2009) Implications of changing climate for global wildland fire. Int J Wildland Fire 18:483-507

Ghesquière E, Marchand G (2010) Le Mésolithique en France: Archéologie des derniers chasseurs-cueilleurs. La Découverte, Paris

Giannakopoulos C, Le Sager P, Bindi M, Moriondo M, Kostopoulou E, Goodess CM (2009) Climatic changes and associated impacts in the Mediterranean resulting from a 2 degrees $\mathrm{C}$ global warming. Glob Planet Change 68:209-224

González-Samperíz P, Valéro-Garcés BL, Moreno A, Jalut G, GarcíaRuíz JM, Martí Bono C, Delgado-Huerta A, Otto T, Dedoubat JJ (2006) Climate variability in the Spanish Pyrenees for the last 30000 year: El Portalet peatbog sequence. Quat Res 66:38-52

Heiri O, Millet L (2005) Reconstruction of Late Glacial summer temperatures from chironomid assemblages in Lac Lautrey (Jura, France). J Quat Sci 20:33-44

Heiri O, Lotter AF, Lemcke G (2001) Loss on ignition as a method for estimating organic and carbonate content in sediments: reproducibility and comparability of results. J Paleolimnol 25:101-110

Heiri O, Brooks SJ, Birks HJB, Lotter AE (2011) A 274-lake calibration data-set and inference model for chironomid-based summer air temperature reconstruction in Europe. Quat Sci Rev 30:3, 445-453, 456

Higuera PE, Brubaker LB, Anderson PM, Hu FS, Brown TA (2009) Vegetation mediated the impacts of postglacial climate change on fire regimes in the south-central Brooks Range, Alaska. Ecol Monogr 79:201-219

Innes JB, Blackford JJ (2003) The ecology of late Mesolithic woodland disturbances: model testing with fungal spore assemblage data. J Archaeol Sci 30:185-194

Jalut G, Marti JM, Fontugne M, Delibrias G, Vilaplana JM, Julia R (1992) Glacial to interglacial vegetation changes in the northern and southern pyrenees: deglaciation, vegetation cover and chronology. Quat Sci Rev 11:449-480

Jalut G, Michels VTI, Dedoubat JJ, Otto T, Ezquerra J, Fontugne M, Belet JM, Bonnet L, De Celis AG, Redondo-Vega JM, VidalRomani JR, Santos L (2010) Palaeoenvironmental studies in NW Iberia (Cantabrian range): vegetation history and synthetic approach of the last deglaciation phases in the western Mediterranean. Palaeogeogr Palaeoclim Palaeoecol 297:330-350

Kaltenrieder P, Procacci G, Vanniere B, Tinner W (2010) Vegetation and fire history of the Euganean Hills (Colli Euganei) as recorded by Late-Glacial and Holocene sedimentary series from Lago della Costa (northeastern Italy). Holocene 20:679-695

Killick R, Eckley IA (2011) Changepoint: An R package for changepoint analysis. http://www.lancs.ac.uk/ killick/Pub/ KillickEckley2011.pdf. Accessed 25 Nov 2013

Krawchuk MA, Moritz MA, Parisien M.-A, Van Dorn J, Hayhoe K (2009) Global pyrogeography: the current and future distribution of wildfire. PLoS ONE 4(4):e5102. doi:10.1371/journal.pone. 0005102

Lotter AF, Eicher U, Siegenthaler U, Birks HJB (1992) Late-Glacial climatic oscillations as recorded in swiss lake-sediments. J Quat Sci 7:187-204

Lowe JJ, Rasmussen SO, Bjorck S, Hoek WZ, Steffensen JP, Walker MJC, Yu ZC, Grp I (2008) Synchronisation of palaeoenvironmental events in the North Atlantic region during the last termination: a revised protocol recommended by the INTIMATE group. Quat Sci Rev 27:6-17 
Magny M, Aalbersberg G, Begeot C, Benoit-Ruffaldi P, Bossuet G, Disnar JR, Heiri O, Laggoun-Defarge F, Mazier F, Millet L, Peyron O, Vanniere B, Walter-Simonnet AV (2006a) Environmental and climatic changes in the Jura mountains (eastern France) during the Late-Glacial-Holocene transition: a multiproxy record from Lake Lautrey. Quat Sci Rev 25:414-445

Magny M, De Beaulieu JL, Drescher-Schneider R, Vanniere B, WalterSimonnet AV, Millet L, Bossuet G, Peyron O (2006b) Climatic oscillations in central Italy during the Last Glacial-Holocene transition: the record from Lake Accesa. J Quat Sci 21:311-320

Marlon JR, Bartlein PJ, Walsh MK, Harrison SP, Brown KJ, Edwards ME, Higuera PE, Power MJ, Anderson RS, Briles C, Brunelle A, Carcaillet C, Daniels M, Hu FS, Lavoie M, Long C, Minckley T, Richard PJH, Scott AC, Shafer DS, Tinner W, Umbanhowar CE, Whitlock C (2009) Wildfire responses to abrupt climate change in North America. Proc Natl Acad Sci USA 106:2,519-2,524

Mason SLR (2000) Fire and Mesolithic subsistence: managing oaks for acorns in northwest Europe? Palaeogeogr Palaeoclim Palaeoecol 164:139-150

Meyers PA, Ishiwatari R (1993) Lacustrine organic geochemistry: an overview of indicators of organic-matter sources and diagenesis in lake-sediments. Org Geochem 20:867-900

Millet L, Rius D, Galop D, Heiri O, Brooks SJ (2012) Chironomidbased reconstruction of Late-Glacial summer temperatures from the Ech palaeolake record (French western Pyrenees). Palaeogeogr Palaeoclim Palaeoecol 315:86-99

Muñoz-Sobrino C, Ramil-Rego P, Gómez-Orellana L (2007) Late Würm and early Holocene in the mountains of northwest Iberia: biostratigraphy, chronology andtree colonization. Veget Hist Archaeobot 16:223-240

Pausas JG, Fernandez-Munoz S (2012) Fire regime changes in the Western Mediterranean Basin: from fuel-limited to droughtdriven fire regime. Clim Change 110:215-226

Pechony O, Shindell DT (2010) Driving forces of global wildfires over the past millennium and the forthcoming century. Proc Natl Acad Sci USA 107:19,167-19,170

Pezzatti GB, Zumbrunnen T, Bürgi M, Ambrosetti P, Conedera M (2013) Fire regime shifts as a consequence of fire policy and socio-economic development: an analysis based on the change point approach. For Policy Econ 29:7-18

Power MJ, Marlon J, Ortiz N et al (2008) Changes in fire regimes since the Last Glacial maximum: an assessment based on a global synthesis and analysis of charcoal data. Clim Dyn 30:887-907

Ralska-Jasiewiczowa M, Nalepka D, Goslar T (2003) Some problems of forest transformation at the transition to the oligocratic/Homo sapiens phase of the Holocene interglacial in northern lowlands of central Europe. Veget Hist Archaeobot 12:233-247

Reille M, Andrieu V (1995) The late Pleistocene and Holocene in the Lourdes basin, Western Pyrenees, France: new pollen analytical and chronological data. Veget Hist Archaeobot 4:1-21

Reimer PJ, Baillie MGL, Bard E, Bayliss A, Beck JW, Blackwell PG, Bronk Ramsey C, Buck CE, Burr GS, Edwards RL, Friedrich M, Grootes PM, Guilderson TP, Hajdas I, Heaton TJ, Hogg AG, Hughen KA, Kaiser KF, Kromer B, McCormac FG, Manning SW, Reimer RW, Richards DA, Southon JR, Talamo S, Turney CSM, van der Plicht J, Weyhenmeyer CE (2009) Intcal09 and marine09 radiocarbon age calibration curves, 0-50000 years cal. B.P. Radiocarbon 51:1,111-1,150

Rhodes AN (1998) A method for the preparation and quantification of microscopic charcoal from terrestrial and lacustrine sediment cores. Holocene 8:113-117

Rius D, Vanniere B, Galop D (2009) Fire frequency and landscape management in the northwestern Pyrenean piedmont, France, since the early Neolithic (8000 cal. в.P.). Holocene 19:847-859
Rius D, Vanniere B, Galop D, Richard H (2011) Holocene fire regime changes from multiple-site sedimentary charcoal analyses in the Lourdes basin (Pyrenees, France). Quat Sci Rev 30:1,696-1,709

Rius D, Vanniere B, Galop D (2012) Holocene history of fire, vegetation and land use from the central Pyrenees (France). Quat Res 77:54-64

R Development Core Team (2011) R: a Language and Environment for Statistical Computing. R Foundation for Statistical Computing, Vienna, Austria, ISBN 3-900051-07-0. http://www.R-project.org/. Accessed 25 Nov 2013

Schneider SH, Semenov S, Patwardhan A, Burton I, Magadza CHD, Oppenheimer M, Pittock AB, Rahman A, Smith JB, Suarez A, Yamin F (2007) Assessing key vulnerabilities and the risk from climate change. In: Parry ML, Canziani OF, Palutikof JP, Van der Linden PJ, Hanson CE (eds) Climate Change 2007: Impacts, adaptation and vulnerability. contribution of working group II to the fourth assessment report of the intergovernmental panel on climate change. Cambridge University Press, Cambridge, pp 779-810

Swetnam TW, Allen CD, Betancourt JL (1999) Applied historical ecology: using the past to manage for the future. Ecol Appl 9:1,189-1,206

Ter Braak CJF, Juggins S (1993) Weighted averaging partial leastsquares regression (wa-pls): an improved method for reconstructing environmental variables from species assemblages. Hydrobiologia 269:485-502

Tinner W, Conedera M, Gobet E, Hubschmid P, Wehrli M, Ammann B (2000) A palaeoecological attempt to classify fire sensitivity of trees in the Southern Alps. Holocene 10:565-574

Valdeyron N (2008) The Mesolithic in France. In: Bailey G, Spikins P (eds) Mesolithic Europe. Cambridge University Press, Cambridge, pp 182-202

Van der Hammen T, Van Geel B (2008) Charcoal in soils of the Allerod-Younger Dryas transition were the result of natural fires and not necessarily the effect of an extra-terrestrial impact. Netherl J Geosci Geol en Mijnbouw 87:359-361

Vanniere B, Bossuet G, Walter-Simonnet AV, Ruffaldi P, Adatte T, Rossy M, Magny M (2004) High-resolution record of environmental changes and tephrochronological markers of the Last Glacial-Holocene transition at Lake Lautrey (Jura, France). J Quat Sci 19:797-808

Wagner-Cremer F, Lotter AF (2011) Spring-season changes during the Late pleniglacial and bolling/allerod interstadial. Quat Sci Rev 30:1,825-1,828

Walker MJC (1995) Climatic changes in Europe during the Last Glacial/Interglacial transition. Quat Int 28:63-76

Walker IR (2001) 3-Midges: Chironomidae and related Diptera. In: Last WM, Smol JP (eds) Tracking Environmental change using lake sediments: Zoological Indicators, vol 4. Kluwer, Dordrecht, pp 43-66

Westerling AL, Hidalgo HG, Cayan DR, Swetnam TW (2006) Warming and earlier spring increase western US forest wildfire activity. Science 313:940-943

Whitlock C, Millspaugh SH (1996) Testing the assumptions of fire history studies: an examination of modern charcoal accumulation in Yellowstone National Park, USA. Holocene 6:7-15

Zolitschka B (1998) A 14000 year sediment yield record from western Germany based on annually laminated lake sediments. Geomorph 22:1-17

Zumbrunnen T, Pezzatti GB, Menendez P, Bugmann H, Burgi M, Conedera M (2011) Weather and human impacts on forest fires: 100 years of fire history in two climatic regions of Switzerland. For Ecol Manag 261:2,188-2,199 